\title{
Association of the copepod Macrosetella gracilis with the cyanobacterium Trichodesmium spp. in the North Pacific Gyre
}

\author{
Renate Eberl ${ }^{1,2, *}$, Edward J. Carpenter ${ }^{1}$ \\ ${ }^{1}$ Romberg Tiburon Center for Environmental Studies, San Francisco State University, 3152 Paradise Drive, \\ California 94920-1205, USA \\ ${ }^{2}$ University of California Davis, Department of Ecology and Evolution, One Shields Avenue, Davis, \\ California 95616-8507, USA
}

\begin{abstract}
The harpacticoid copepod Macrosetella gracilis is found in pelagic habitats in tropical and subtropical oceans associated with colonies of the $\mathrm{N}_{2}$ fixing cyanobacterium Trichodesmium spp. In the central North Pacific near Hawaii, M. gracilis was abundant $\left(1.8 \pm 1.4\right.$ [SD] M. gracilis adults ${ }^{-3}$ and $4.7 \pm 3.9 \mathrm{M}$. gracilis copepodites $\mathrm{m}^{-3}$ ) and constituted an average of $10.8 \%$ of the total copepod population. However, we observed no statistically discernable correlation between $M$. gracilis and Trichodesmium spp. abundances, suggesting that availability of Trichodesmium spp. did not limit the abundance of $M$. gracilis during our study. In previous laboratory studies $M$. gracilis had been shown to have the ability to ingest Trichodesmium spp. trichomes and appeared immune to cyanobacterial toxins harmful to other species of copepods. Natural abundance of stable isotopes $\left(\delta^{15} \mathrm{~N}, \delta^{13} \mathrm{C}\right)$ in copepod tissue from field samples suggested that the diet of M. gracilis was not predominately composed of Trichodesmium spp. as proposed by previous research. Natural abundance of $\delta^{15} \mathrm{~N}$ was similar for M. gracilis (3.06 \pm 2.29$)$, Miracia efferata $(1.83 \pm 0.88)$, and calanoid copepods $(2.7 \pm 1.95)$. No Trichodesmium spp. were observed in M. gracilis gut contents. Trichodesmium spp. was not a predominant food in the diet of this copepod, but colonies of the toxic cyanobacterium could provide shelter from predation and be used as a floating substrate for adult and juveniles of M. gracilis.
\end{abstract}

KEY WORDS: Macrosetella gracilis · Trichodesmium - Copepod feeding - Stable isotopes · Floating substrate $\cdot$ Zooplankton $\cdot$ Oligotrophic oceans $\cdot$ Life history

\section{INTRODUCTION}

The scarcity of buoyant substrates in the open ocean prevents many species with poor swimming ability from living in pelagic habitats unless they can become part of a multi-species association that serves as a float and habitat. The nitrogen-fixing cyanobacterium Trichodesmium spp. is an important species that can provide a floating habitat in the open ocean (Sheridan et al. 2002). Trichodesmium spp. is one of the most abundant primary producers in oligotrophic tropical and subtropical oceans and can provide an important nitrogen source for higher trophic levels (Letelier \& Karl
1996, Capone et al. 1997, Carpenter et al. 1999, Post et al. 2002). Macrosetella gracilis is a harpacticoid copepod that occurs globally in tropical and subtropical oceans, and is found in association with blooms of Trichodesmium spp. (Huys \& Böttger-Schnack 1994). Harpacticoid copepods are predominately benthic, but M. gracilis and other copepods in the family Miraciidae are some of the few species that have evolved a pelagic life style (Huys \& Böttger-Schnack 1994). M. gracilis is a poor swimmer (Hwang \& Turner 1995) and uses Trichodesmium spp. colonies as a float, as a nursery ground for its nauplii, and as a potential food source (Huys \& Böttger-Schnack 1994, O'Neil 1998). 
While an ecological link between Macrosetella gracilis and Trichodesmium spp. is apparent, few data exist concerning the abundance, life-history, and feeding habits of $M$. gracilis in its natural habitat. The relative abundance of $M$. gracilis among tropical copepods is poorly known, although Böttger-Schnack \& Schnack (1989) estimated that $M$. gracilis comprises 1 to $3 \%$ of adult tropical copepods in the Red Sea. Calef \& Grice (1966) showed that $M$. gracilis abundance in the western tropical Atlantic closely tracked Trichodesmium spp. abundance, and they found no $M$. gracilis in the absence of Trichodesmium spp. A positive correlation between Trichodesmium spp. and M. gracilis abundances was also found in the Red Sea (Calef \& Grice 1966, Böttger-Schnack \& Schnack 1989, BöttgerSchnack 1991). However, no abundance data appears to be available for the North Pacific Gyre. This study used quantitative stratified sampling to determine the abundance of $M$. gracilis near Hawaii and to determine how this copepod species is distributed in relation to Trichodesmium abundance.

The diazotroph Trichodesmium spp. provides a nitrogen source that is not readily accessible to generalized grazers in oligotrophic waters due to the production of neurotoxins that may lead to grazer avoidance (Hawser et al. 1991, Cox et al. 2005). Hawser et al. (1992) demonstrated that Trichodesmium thiebautii was toxic to all copepods tested except Macrosetella gracilis and Miracia efferata. It has been shown in laboratory experiments that $M$. gracilis can feed on Trichodesmium spp. (Roman 1978, O'Neil \& Roman 1994, O'Neil et al 1996). The mechanism M. gracilis employs to protect itself from the effects of the cyanobacterial toxin is not known, nor is the extent to which M. gracilis feeds on Trichodesmium spp. in the wild. It is unclear, whether M. gracilis feeds on other species of pelagic phytoplankton, but results from laboratory studies by O'Neil et al. (1996) suggest that it does not.

The present study investigated the natural diet of Macrosetella gracilis by using 2 methods: gut content analysis and natural abundance of stable isotopes in copepod tissue. Autofluorescence of photosynthetic pigments can be used for identification of gut contents with epifluorescence microscopy. Studies of naturally occurring nitrogen and carbon stable isotopes have been successfully used in ecological studies to investigate trophic relationships in aquatic environments (DeNirot \& Epstein 1981, Lajtha \& Michener 1994, Michener \& Schell 1994, Cabana \& Rasmussen 1996, Jennings \& Warr 2003). Organisms that can fix molecular nitrogen will have characteristically lower $\delta^{15} \mathrm{~N}$ ratios than those that must assimilate other forms of inorganic nitrogen such as ammonium or nitrate (DeNirot \& Epstein 1981). It has been shown that the diazotroph Trichodesmium spp. has the lowest $\delta^{15} \mathrm{~N}$ and highest $\delta^{13} \mathrm{C}$ values of any phytoplankter reported to date (Minagawa \& Wada 1986, Carpenter et al. 1997). Grazing animals show an average enrichment per trophic level of around 3.5\%o for nitrogen and 1\% for carbon (Peterson \& Fry 1987, Michener \& Schell 1994). Thus, one would expect M. gracilis and Miracia efferata, as grazers on Trichodesmium spp., to have distinctly lower $\delta^{15} \mathrm{~N}$ and higher $\delta^{13} \mathrm{C}$ in their tissues than calanoid copepods that do not feed on Trichodesmium spp.

The goals of this study were to: (1) obtain quantitative data on the distribution of Macrosetella gracilis and other zooplankton in the North Pacific Gyre and discern how they correlate with Trichodesmium spp. distribution; and (2) determine the natural diet of $M$. gracilis through gut content analysis and natural abundance of stable isotopes in copepod tissue.

\section{MATERIALS AND METHODS}

Sample collection and enumeration. Zooplankton samples were collected near the Hawaiian Islands $\left(18^{\circ} 30.01^{\prime} \mathrm{N}\right.$ to $21^{\circ} 00.78^{\prime} \mathrm{N}$ and $154^{\circ} 49.41^{\prime} \mathrm{W}$ to $162^{\circ} 13.06^{\prime} \mathrm{W}$ ) with a $0.5 \mathrm{~m}$ mouth diameter multiple

Table 1. Sampling design for Macrosetella gracilis and Trichodesmium spp. during Cruise MPO9, with station number, sampling dates, station coordinates, sea-surface temperature (SST), salinity (Sal), MOCNESS sampling for zooplankton collection and Niskin bottle sampling for Trichodesmium spp. abundance (MOC), natural isotope data of copepods (I) and number of $M$. gracilis sampled for gut content analysis (G)

\begin{tabular}{|c|c|c|c|c|c|c|c|c|}
\hline Stn & Date (2003) & Latitude (N) & Longitude (W) & $\operatorname{SST}\left({ }^{\circ} \mathrm{C}\right)$ & Sal & MOC & I & G \\
\hline 14 & 8 Aug & $18^{\circ} 30.01^{\prime}$ & $157^{\circ} 00.00^{\prime}$ & 26.85 & 34.77 & Yes & No & - \\
\hline 16 & 10 Aug & $19^{\circ} 29.59^{\prime}$ & $157^{\circ} 00.01^{\prime}$ & 26.50 & 34.91 & Yes & Yes & 6 \\
\hline 17 & 12 Aug & $19^{\circ} 32.14^{\prime}$ & $158^{\circ} 58.75^{\prime}$ & 27.36 & 35.05 & Yes & Yes & 3 \\
\hline 18 & 14 Aug & $20^{\circ} 32.11^{\prime}$ & $160^{\circ} 59.87^{\prime}$ & 27.38 & 35.02 & Yes & Yes & 5 \\
\hline 19 & 15 Aug & $21^{\circ} 00.78^{\prime}$ & $158^{\circ} 59.70^{\prime}$ & 27.07 & 34.91 & Yes & Yes & - \\
\hline 21 & 18 Aug & $20^{\circ} 15.18^{\prime}$ & $159^{\circ} 11.32^{\prime}$ & 27.39 & 35.11 & No & Yes & - \\
\hline 22 & 20 Aug & $19^{\circ} 06.26^{\prime}$ & $162^{\circ} 13.62^{\prime}$ & 27.35 & 35.02 & No & Yes & 4 \\
\hline 23 & 21 Aug & $20^{\circ} 30.04^{\prime}$ & $161^{\circ} 30.02^{\prime}$ & 27.58 & 34.97 & No & Yes & - \\
\hline
\end{tabular}


opening/closing net and environmental sensing system (MOCNESS), fitted with 7 nets $(64 \mu \mathrm{m}$ mesh), and towed at 1 knot for 10 to 20 min (Table 1, Fig. 1). Samples were taken between 0 and $150 \mathrm{~m}$ at approximately $20 \mathrm{~m}$ depth intervals. Samples were preserved in $4 \%$ buffered formaldehyde, and the total sample volume was counted under a dissecting microscope.

Water samples for Trichodesmium spp. abundance were collected using 101 Niskin bottles mounted on a CTD rosette system. Samples were collected at the same stations and depths within a maximum of $3 \mathrm{~h}$ of the MOCNESS tow. Concentrations of free trichomes and trichomes in colonies of Trichodesmium spp. for each sample were determined following gravity filtration methods described by Carpenter et al. (2003). This method allowed minimal disturbance of colonies and permitted counting of trichomes in both colonial and free states. Trichomes were enumerated on board within $24 \mathrm{~h}$ of collection at $400 \times$ magnification using a Zeiss Axioskop microscope with epifluorescence and green excitation.

Abundance data were examined for departure from homogeneity of variances using Levene's test and for normality using Andersen-Darling tests. One-way ANOVA (Minitab 13) was used to test whether there were statistical differences in Macrosetella gracilis adult and $M$. gracilis copepodite abundances among either different depths or different stations (Sokal \& Rohlf 1995). A Pearson's product-moment correlation coefficient ( $\rho$ ) was calculated (Minitab 13) to determine the relationships between the abundance of $M$. gracilis adults and Trichodesmium spp., and M. gracilis copepodites and Trichodesmium spp.

Gut content analysis. Macrosetella gracilis were collected from surface plankton tows (0 to $20 \mathrm{~m}$ ) at 4 different stations (Table 1), rinsed 3 times in $0.2 \mu \mathrm{m}$ filtered seawater (FSW) to remove phytoplankton attached to their carapaces, and frozen in liquid nitrogen with 50 to $100 \mu$ l of FSW within an hour after collection and kept frozen until dissection. Fullness level of $M$. gracilis guts was rated as full, approximately half full, or empty by visual inspection prior to dissection. Copepods were dissected, and gut contents were observed under epifluorescence green and blue light excitation using $40 \times$ and $100 \times$ magnification. Only cells with sufficient shape and size distinctiveness that allowed identification of the cell origin were counted and photographed.

Natural abundance of stable isotopes. Copepods collected at 7 different stations (Table 1, Fig. 1) were removed from plankton tows (0 to $20 \mathrm{~m}$ ) and sorted. Individual Macrosetella gracilis, Miracia efferata, and calanoid copepods from the same station were rinsed 3 times in FSW. Twenty to thirty copepods of either M. gracilis, M. efferata, or calanoid copepods were

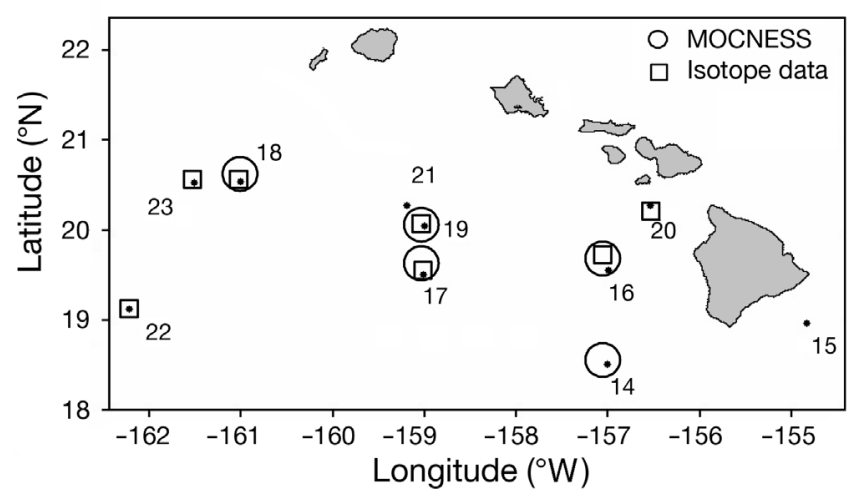

Fig. 1. Macrosetella gracilis and Trichodesmium spp. sampling stations during Cruise MPO9 in the Pacific near the Hawaiian islands

separated by species or group for calanoid copepods, and each category was filtered through a Swinnex filter onto pre-combusted $\left(550^{\circ} \mathrm{C}, 24 \mathrm{~h}\right)$ Whatman $\mathrm{GF} / \mathrm{F}$ filters. The filters were frozen at $-20^{\circ} \mathrm{C}$ until analysis. In the laboratory, the filters with the copepods were dried for $3 \mathrm{~d}$ at $50^{\circ} \mathrm{C}$. Dried filter samples were pelletized in tin foil and analyzed for isotopic and elemental composition using an Isoprime mass spectrometer configured with continuous flow to an elemental analyzer. Atmospheric air was used as the standard for nitrogen, and Pee Dee Belemite, as the standard for carbon. Results of natural abundance of stable isotopes are reported as delta values $\left(\delta^{13} \mathrm{C}\right.$ and $\left.\delta^{15} \mathrm{~N}\right)$, and all units are per mille $(\%)$. Delta values are not absolute abundances, but differences between sample readings and a standard, such that:

$$
\delta[\%]=\left[\left(R_{\text {sample }} / R_{\text {standard }}\right)-1\right] \times 1000
$$

where $R$ is expressed as the ratio of the heavy to the light isotope.

One-way ANOVA (or Kruskal-Wallis tests when the data did not fit the assumption of normality) (Minitab 13) were used to examine differences in the natural abundance of stable carbon and nitrogen isotope ratios among the different groups of copepods (Sokal \& Rohlf 1995).

\section{RESULTS}

\section{Zooplankton and Trichodesmium spp. abundances}

Hydrographic conditions during August 2003 were typical for the season, with sea-surface temperatures ranging from 26.5 to $27.6^{\circ} \mathrm{C}$ and surface salinity ranging from 34.8 to 35.1 (Table 1).

Counts of the total sample volume averaged $523 \pm$ 231 (SD) individual zooplankters. Individuals of Macrosetella gracilis, including both adults and copepodites, 


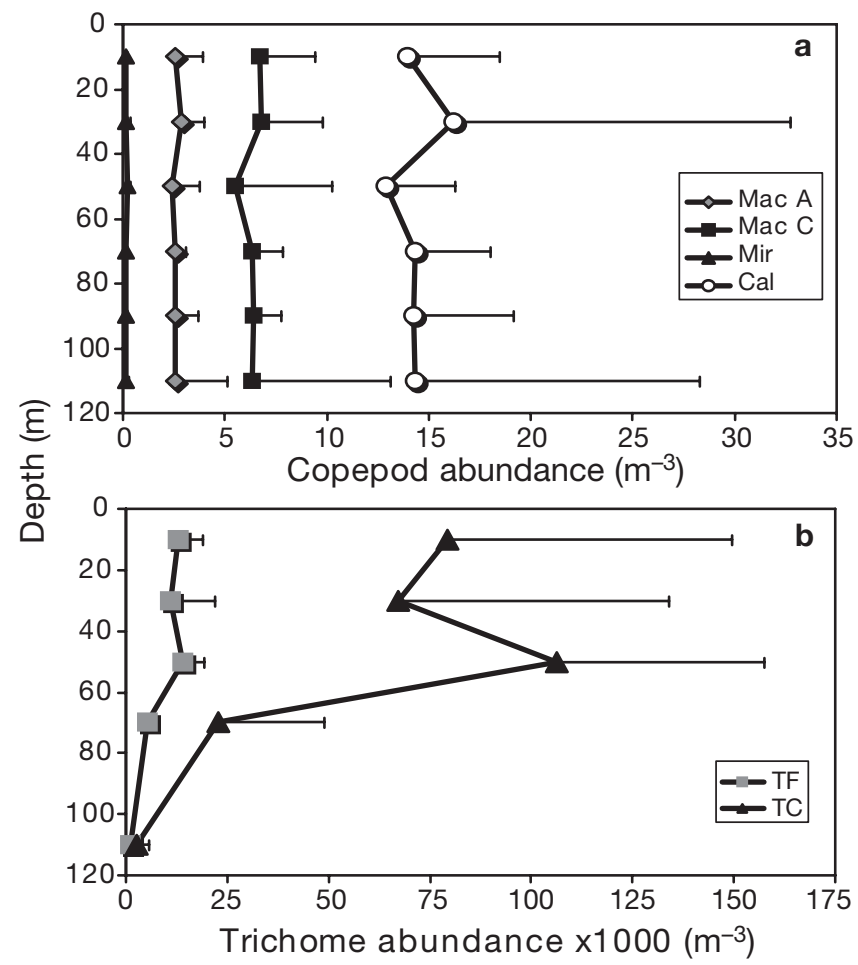

Fig. 2. Average copepod and Trichodesmium spp. abundances (+SD) at different depths: (a) Macrosetella gracilis adults (Mac A) and copepodites (Mac C), Miracia efferata (Mir), and calanoid copepods (Cal) and (b) free trichomes (TF) and trichomes in colonies (TC) $\left(\times 1000 \mathrm{~m}^{-3}\right)$

were present in all our samples, with abundances ranging from 0.4 to 4.3 adults $\mathrm{m}^{-3}$ and from 0.5 to 19.1 copepodites $\mathrm{m}^{-3}$ (Fig. 2a). We found on average $1.8 \pm$ 1.4 M. gracilis adults $\mathrm{m}^{-3}$ and $4.7 \pm 3.9 \mathrm{M}$. gracilis copepodites $\mathrm{m}^{-3}$. The number of $M$. gracilis copepodites was higher than the number of $M$. gracilis adults for all samples. Miracia efferata, also in the family Miraciidae, had consistently lower overall abundances than M. gracilis, with abundances ranging from 0 to 0.6 ind. $\mathrm{m}^{-3}$. Total copepod abundance averaged $18.4 \pm$ 16.2 adult copepods $\mathrm{m}^{-3}$, with $M$. gracilis comprising, on average, $10.8 \pm 5.1 \%$ of the total number of copepods, but never $<3.5 \%$, whereas calanoid copepods comprised $61.9 \pm 7.7 \%$ of all copepods (Fig. 2a).

Trichomes of Trichodesmium spp. were present in all samples, with highest abundances in the water column above $60 \mathrm{~m}$ (Fig. 2b), and declined when the light level decreased below 5 to $10 \%$ of surface irradiance. We did not find a similar decline in Macrosetella gracilis densities at lower depths. Total trichome densities averaged $77.0 \pm 88.9 \times 10^{3}$ trichomes $\mathrm{m}^{-3}$ of seawater (Fig. 2b). On average, $86.4 \%$ of trichomes occurred in colonies; the rest existed as free trichomes. Overall, we found no statistically discernable correlation between
Trichodesmium spp. abundance and the abundance of either $M$. gracilis adults $(\rho=0.088, p=0.697)$ or copepodites $(\rho=0.052, p=0.818)$ when abundances from all stations and depths were pooled (Fig. 3). However, there seems to be a clear trend in the copepodite to Trichodesmiun correlation, slope $=0$, indicating only $\mathrm{a}$ small abundance of Trichodesmium is necessary for copepodite survival.

\section{Gut content analysis}

Gut contents of a total of 18 copepods from 4 stations were examined (Table 1). Visual inspection of gut fullness before dissection revealed that $35 \%$ of the copepods had completely full guts, $24 \%$ partially full guts, and $41 \%$ empty guts. No Trichodesmium spp. filaments were noted during dissection, but single coccoid cyanobacterial cells were observed in 6 of 18 individuals $(33.3 \%)$. When unicellular cyanobacteria were observed, they were found in copepods with either full $(n=4)$ or partially full guts $(n=2)$. One individual contained a fragment of the diatom Rhizosolenia sp. with 2 individuals of the symbiotic cyanobacterium Richelia intracellularis. Most of the gut contents, however, could not be identified.

\section{Natural abundance of stable isotopes in copepod tissue}

Natural abundances of $\delta^{15} \mathrm{~N}$ were similar for Macrosetella gracilis $(3.06 \pm 2.29)$, Miracia efferata $(1.83 \pm$

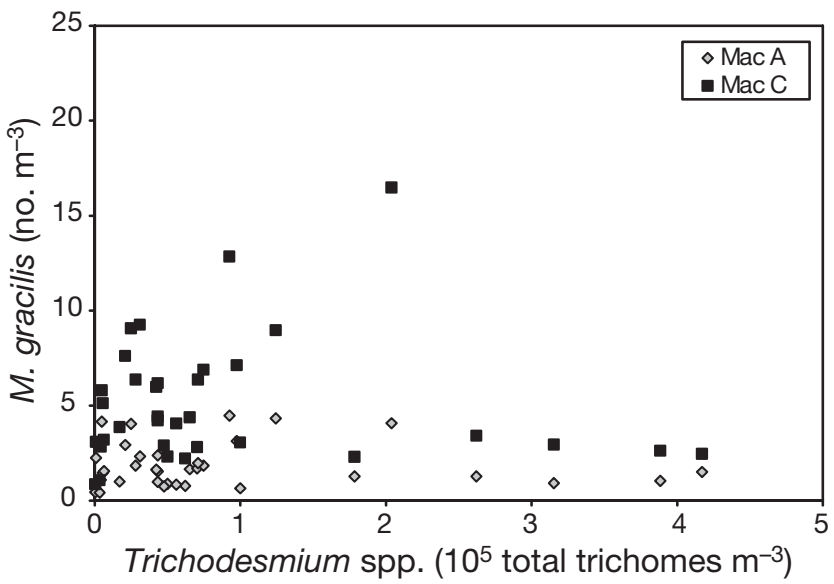

Fig. 3. Macrosetella gracilis and Trichodesmium spp. Correlation plot of $M$. gracilis adults (Mac A) and M. gracilis copepodites (Mac C) with Trichodesmium spp. (total trichomes) abundance shows no significant correlation between the abundance of $M$. gracilis adults and Trichodesmium spp. (Mac A: $\rho=0.088, p=0.697$ ) or between $M$. gracilis copepodites and Trichodesmium spp. (Mac C: $\rho=0.052, p=0.818$ ) 
Table 2. Natural abundance of stable isotopes $\left(\delta^{15} \mathrm{~N}, \delta^{13} \mathrm{C}\right)$ in copepod tissue for different taxa. $\mathrm{n}$ : number of samples

\begin{tabular}{|lrrrrr|}
\hline \multirow{2}{*}{ Taxon } & $\mathrm{n}$ & \multicolumn{2}{c}{$\delta^{15} \mathrm{~N}$} & \multicolumn{2}{c|}{$\delta^{13} \mathrm{C}$} \\
& & Mean & $\mathrm{SD}$ & Mean & $\mathrm{SD}$ \\
\hline Macrosetella gracilis & 13 & 3.06 & 2.29 & -22.28 & 0.67 \\
Miracia efferata & 7 & 1.83 & 0.88 & -20.91 & 0.45 \\
Calanoid copepods & 3 & 2.70 & 1.95 & -19.42 & 0.45 \\
\hline
\end{tabular}

0.88), and calanoid copepods $(2.7 \pm 1.95)$ (KruskalWallis, $H=0.764, \mathrm{p}=0.682$; Table 2). However, there were statistically discernible and ecologically significant differences in $\delta^{13} \mathrm{C}$ values among the different copepod groups (1-way ANOVA, df =2, $F=32.175$, p < 0.005 ; Table 2). There do appear to be 2 clusters within the Macrosetella distributions, with little overlap with Miracia and no overlap with the calanoids. These clusters were not statistically discernible in the present study. A dual stable isotope plot of $\delta^{15} \mathrm{~N}$ and $\delta^{13} \mathrm{C}$ data was used to compare the 3 different copepod groups analyzed in this study with published natural isotope values of Trichodesmium spp. (Fig. 4). Natural abundance of stable isotopes for all 3 groups of copepods differed from the published values for Trichodesmium spp. by amounts other than the expected 3.5 and $1 \%$ enrichment per trophic level for nitrogen and carbon, respectively (Fig. 4).

\section{DISCUSSION}

\section{Macrosetella gracilis and Trichodesmium spp. abundance}

Macrosetella gracilis abundances from this study in the Pacific were lower than peak abundance estimates from the Red Sea (Böttger-Schnack \& Schnack 1989, Böttger-Schnack 1991) and the Atlantic (Calef \& Grice 1966). Trichodesmium spp. were present in all samples analyzed in this study, yet no significant positive correlation between $M$. gracilis and Trichodesmium spp. abundance was detected, suggesting that factors other than substrate availability may limit the abundance of the copepod. Despite its poor swimming ability and the specialized use of Trichodesmium spp. as a floating substrate for nauplii and copepodites, $M$. gracilis adults may not be highly dependant on Trichodesmium spp. colonies during all life-history stages. M. gracilis was found at depths $>100 \mathrm{~m}$, where Trichodesmium spp. no longer occurred due to light limitation. Furthermore, M. gracilis has been encountered on rare occasions in waters too cold to sustain Trichodesmium spp. (Huys \& Böttger-Schnack 1994). M. gracilis was also found in a

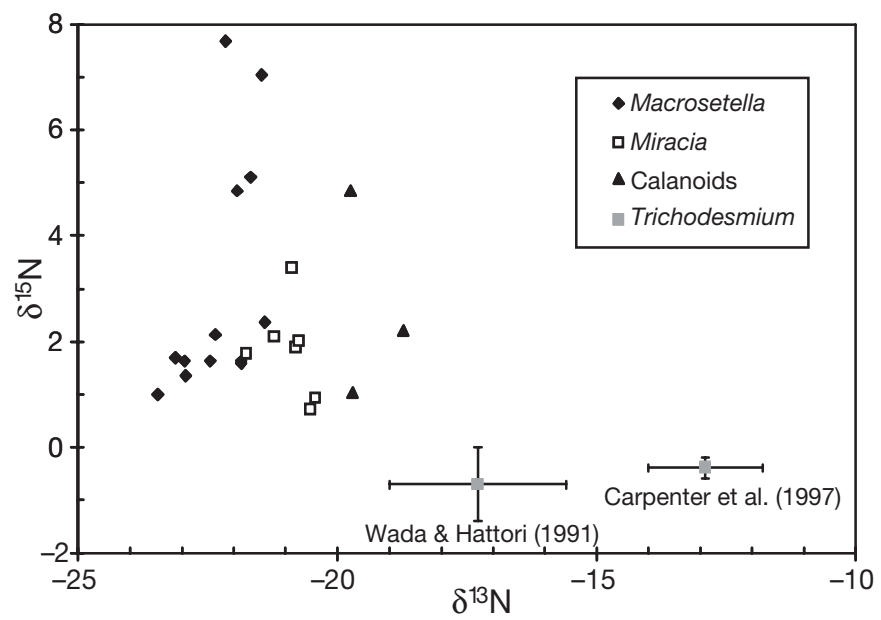

Fig. 4. Macrosetella gracilis, Miracia efferata and calanoid copepods. Dual isotope plot of natural abundance of stable isotopes $\delta^{15} \mathrm{~N}$ and $\delta^{13} \mathrm{C}$ of copepod tissue (published Trichodesmium spp. values are shown for comparison)

deep population below the photic zone in the Red Sea, where no Trichodesmium spp. occur (Böttger-Schnack \& Schnack 1989). Presence of Trichodesmium spp. colonies may only be necessary to confer reproductive success (Björnberg 1965, but may have less influence on abundance of adults than previously assumed (Calef \& Grice 1966). It should be acknowledged, however, that sampling in this study occurred only in areas where Trichodesmium was present, ranging between $23 \times 10^{3}$ and $136 \times 10^{3}$ trichomes $\mathrm{m}^{-3}$, and Trichodesmium spp. may therefore have always been present in quantities that were high enough not to limit the abundance of the copepod. Additionally, the short duration of the sampling regime did not allow tracking of copepod abundances over multiple lifecycles. Future studies should include abundance data for earlier lifehistory stages of $M$. gracilis that could not be quantitatively sampled in this study.

While it is possible that Macrosetella gracilis uses other types of aggregates as a floating substrate, we have no data to confirm this. Other copepod speciesfor example the morphologically similar, but not closely related harpacticoid genus Microsetella-are often found associated with marine snow (Alldredge 1972, Ohkutsa et al. 1993, Steinberg 1994), but we have found no record that $M$. gracilis is associated with marine snow. Since Trichodesmium spp. is toxic, the association with the cyanobacterium could provide a shelter from predation. This shelter hypothesis needs to be tested in future studies.

Our study did not specifically address the question of selective predation on Macrosetella gracilis. The hydroid Pelagiana trichodesmiae and chaetognaths are known to feed on $M$. gracilis adults and juveniles 
(Borstad \& Brinckmann-Voss 1978, Post et al. 2002) and could have a significant impact on copepod abundance. The hydroid $P$. trichodesmiae, reported to date only from the Atlantic Ocean, preys extensively on nauplii and copepodites of $M$. gracilis (Borstad \& Brinckmann-Voss 1978), but did not occur in our samples, so this source of predation likely did not play a role in limiting the abundance of the $M$. gracilis populations sampled. Chaetognaths were present in all samples (range 0.5 to 11.9 ind. $\mathrm{m}^{-3}$ ), and predation by chaetognaths could be important in reducing M. gracilis abundance. Based on analysis of omega fatty acids of zooplankton samples from the Red Sea, Post et al. (2002) concluded that chaetognaths fed on M. gracilis.

The consistently higher abundances of Macrosetella gracilis copepodites compared to adults and the high number of gravid females ( $41.3 \%$ of all adults; $n=298$ ) suggest that Trichodesmium spp. abundance encountered in our samples - with an average of $68.5 \pm 33.4 \%$ of all trichomes in colonies-is highly favorable to $M$. gracilis reproduction. Previous studies encountered nauplii, copepodites, and gravid females of $M$. gracilis only in areas and at depths of high Trichodesmium abundance (Böttger-Schnack \& Schnack 1989, BöttgerSchnack 1991). Females of M. gracilis carry between 5 and 12 eggs (an average of 6 eggs) in each of the 2 egg sacs, and nauplii hatch successively (Huys \& BöttgerSchnack 1994). Females have been observed to actively attach eggs to Trichodesmium spp. colonies or swim with hatched nauplii-still holding on to the females' caudal rami with modified appendages - to colonies in order to transfer nauplii to the nursery habitat of the colonies (O'Neil 1998). Females were also observed to wait at a colony until all nauplii hatched successively (Björnberg 1965, Huys \& Böttger-Schnack 1994). As an extreme example of parental care, female M. gracilis dropped their caudal rami, and nauplii used them as 'rafts' until they encountered a Trichodesmium spp. colony (R. Eberl pers. obs.), though this observed behavior may be an artifact of culturing conditions in the laboratory, and we do not know if it occurs in the wild. Nauplii and copepodites of $M$. gracilis cling to Trichodesmium spp. filaments with hook-like appendages (Björnberg 1965, Tokioka \& Bieri 1966, Huys \& Böttger-Schnack 1994), but there is no clear consensus as to whether or not nauplii are feeding on Trichodesmium, or using it primarily as a floating substrate to prevent sinking, conserve energy, or find protection from predation (Krishnaswamy 1949, Huys \& BöttgerSchnack 1994).

Since physical substrate in the open ocean is rare, the association of Macrosetella gracilis nauplii and copepodites with Trichodesmium spp. is important for their pelagic existence and evolutionary significant for reproductive success. Björnberg (1965) documented significantly higher survival and developmental rates of M. gracilis nauplii when Trichodesmium spp. colonies were added to the culture. Personal observations of sinking and perishing M. gracilis nauplii during culturing experiments as part of a different study affirmed the reliance of $M$. gracilis on Trichodesmium spp. colonies as a means to remain pelagic. This obligate association of $M$. gracilis nauplii with Trichodesmium spp. was further corroborated by Sheridan et al. (2002) who found $M$. gracilis nauplii and copepodites only on Trichodesmium spp. colonies and not swimming freely in the water column.

\section{Diet of Macrosetella gracilis}

Gut content and natural abundance of stable isotopes in this study suggested that the natural diet of Macrosetella gracilis is not predominately composed of Trichodesmium spp. as previously proposed (O'Neil et al. 1996, O'Neil 1998, 1999). While the above-mentioned studies by O'Neil and colleagues demonstrated in a laboratory setting that $M$. gracilis could ingest Trichodesmium spp. and was not harmed by Trichodesmium toxins, our findings indicated that M. gracilis did not always feed on Trichodesmium spp. in the field when alternate food sources were present.

While Trichodesmium spp. filaments were not observed among the gut contents of Macrosetella gracilis in this study, this finding does not disprove per se that M. gracilis feeds on Trichodesmium spp. Gut content analysis is a descriptive rather than quantitative estimate of the food that $M$. gracilis has consumed recently. The copepod's feeding behavior was not observed in the present study, and it is possible that Trichodesmium cellular contents, and not the cell itself, were ingested by the copepods; however, our isotope data do not support this possibility. Several factors may affect whether or not Trichodesmium spp. (or any other food particles) are found in the gut. Gut residence time of food is difficult to discern, since digestion rates for different phytoplankters may vary. While copepod samples were processed immediately after collection, it is possible that some of the copepods voided their guts during processing (Barmstedt et al. 2000), which could explain the high number $(44 \%)$ of copepods with empty guts. Alternatively, it is possible that not all the copepods were feeding at the time of collection.

However, stable isotope analyses of copepod tissue also suggested that Macrosetella gracilis did not feed predominately on Trichodesmium spp. in the field, and may feed on a mixed diet similar to other copepods examined in this study. Our results for $\delta^{15} \mathrm{~N}$ showed no significant difference between the supposed Trichodesmium spp. feeders (M. gracilis and Miracia effer- 
ata) and other copepods that have been shown to be negatively affected by Trichodesmium toxin and were expected not to feed on Trichodesmium spp. The average $\delta^{13} \mathrm{C}$ values for $M$. gracilis $(-22.3 \pm 0.7 \%$ ) were statistically lower than those of calanoid copepods $(-19.4 \pm 0.6 \%)$ and closer to $\delta^{13} \mathrm{C}$ values of non- $\mathrm{N}_{2}{ }^{-}$ fixing phytoplankton than of Trichodesmium spp. Assuming a 3.5\% enrichment per trophic level for nitrogen and a $1 \%$ enrichment for carbon (Lajtha \& Michener 1994, Michener \& Schell 1994, Carpenter et al. 1997), none of the copepod samples in this study fell within the expected range for $\delta^{15} \mathrm{~N}$ and $\delta^{13} \mathrm{C}$ values when compared to published Trichodesmium spp. data (Minagawa \& Wada 1986, Wada \& Hattori 1991, Carpenter et al. 1997). Lack of significantly different ${ }^{15} \mathrm{~N}$ values among all the groups of copepods investigated suggested that all copepods utilized similar nitrogen sources. The natural abundances of stable isotopes in this study did not support the hypothesis that M. gracilis or M. efferata fed to a large degree on whole Trichodesmium spp. or on their cellular contents. Natural abundance of stable isotope measurements for Trichodesmium spp. collected at the same temporal and geographic location as the copepods used for diet analysis is needed to better understand the degree to which $M$. gracilis consumes and assimilates Trichodesmium spp. Montoya et al. (2002) showed that the low $\delta^{15} \mathrm{~N}$ of suspended particles and zooplankton in the North Atlantic during a bloom of Trichodesmium was consistent with input of new nitrogen by nitrogen fixation. Their study was conducted on size-fractioned zooplankton samples and showed increasing $\delta^{15} \mathrm{~N}$ values with increasing size class. No information, however, was provided on species composition of the samples. Therefore, it is not known whether $M$. gracilis was present in their samples, or what the relative abundance of $M$. gracilis was.

One possible explanation for our findings that Macrosetella gracilis did not feed on Trichodesmium spp. is the recent identification of the neurotoxins $\beta-\mathrm{N}$ methylamino-L-alanine (BMAA) produced by Trichodesmium spp. collected near Hawaii (Cox et al. 2005). The amounts of BMAA measured from seawater samples collected in Hawaii during the time period of this study were 0.0079 and $0.0071 \mu^{-1} g^{-1}$ wet weight. More data are necessary to determine temporal and spatial variation of toxin concentrations during Trichodesmium blooms. While it has been shown that M. gracilis is not affected by the toxins that can harm other zooplankters (O'Neil et al. 1996), M. gracilis may choose other dietary sources if they are available. Future studies on the diet of $M$. gracilis should include analyses of the amount of toxicity present in the micro-layers of water surrounding Trichodesmium spp. colonies, as variable toxin content of Trichodesmium spp. could elicit differ- ent feeding responses. Future work should also investigate a possible correlation between toxin production by Trichodesmium spp. and grazing pressure.

Our data suggest that Macrosetella gracilis does not use Trichodesmium spp. directly for nutrition, but we posit that it may use Trichodesmium colonies as floating habitat for reproduction and possibly as shelter from predation. Whether $M$. gracilis gets nourishment from mucilage and microorganisms associated with colonies as suggested by Borstadt \& Borstadt (1977) requires further studies. $M$. gracilis is a species with low reproductive output per individual, and the association with Trichodesmium spp. may have been a key step in the global distribution of this harpacticoid copepod that would not have been possible with continuation of a benthic lifestyle of adults and nauplii. It appears likely that $M$. gracilis may prefer Trichodesmium species with lower toxin content, as suggested by O'Neil \& Roman (1994), if it feeds at all on the cyanobacterium, but this requires further investigation. In the absence of other food sources, M. gracilis may feed on Trichodesmium spp. as was suggested by previous research (O'Neil \& Roman 1994, O'Neil et al. 1996), but the findings from this study suggest that it feeds on a more varied diet that does not always include Trichodesmium spp. The proportionally higher abundance of copepodites, as well as reproductive females in samples from this study, combined with the lack of evidence that $M$. gracilis feeds predominately on Trichodesmium spp., suggests that the association of $M$. gracilis with Trichodesmium spp. may have developed mainly from the need for a floating habitat rather than for nutritional dependence. We hypothesize that Trichodesmium spp. colonies could act as both nursery ground and/or shelter for predation.

Acknowledgements. We thank D. Capone (University of Southern California) and the participants of Research Cruise MPO9 on RV 'Roger Revelle' for assistance with this research. We thank A. Subramaniam (Columbia University) and T. Gunderson (University of Southern California) for help with MOCNESS sampling, and T. Gunderson for running the stable isotope analyses. We thank the following individuals for valuable discussions of research ideas and review of this manuscript: L. Falcon, R. Cohen, J. Durand, A. Slaughter, and R. Welch. Funding for this project was provided by NSF Grant OCE-0196186 awarded to E.J.C.

\section{LITERATURE CITED}

Alldredge AL (1972) Abandoned larvacean houses: a unique food source in the pelagic environment. Science 117: 885-887

Barmstedt U, Gifford DJ, Irigoien X, Atkinson A, Roman MR (2000) Feeding. In: Harris RP, Wiebe PH, Lenz J, Skjodal HR, Huntley M (eds) ICES zooplankton methodology manual. Academic Press, London, p 297-399 
Björnberg TKS (1965) Observations on the development and the biology of the Miraciidae Dana (Copepoda: Crustacea). Bull Mar Sci 15:512-520

Borstad GA, Borstad LE (1977) The Oscillatoria erythreae (Cyanophyta) community of associates. In: Steward HB (ed) Cooperative investigations of the Caribbean and adjacent regions. FAO, Rome, p 51-57

Borstad GA, Brinckmann-Voss A (1978) On Pelagiana trichodesmiae n. gen., family Pandeidae (Anthomedusae/ Athecatae, Cnidaria), a new hydrozoan associated with the planktonic cyanophyte Trichodesmium thiebautii. Can J Zool 57:1232-1237

Böttger-Schnack R (1991) Seasonal changes in the vertical distribution and size structure of Macrosetella gracilis populations (Copepoda, Harpacticoida) in the Red Sea. In: Uye S, Nishida S, Ho J (eds) Proc 4th Int Conf on Copepoda Bull Plankton Soc Jpn Spec Issue, p 309-320

Böttger-Schnack R, Schnack D (1989) Vertical distribution and population structure of Macrosetella gracilis (Copepoda: Harpacticoida) in the Red Sea in relation to the occurrence of Oscillatoria (Trichodesmium) spp. (Cyanobacteria). Mar Ecol Prog Ser 52:27-31

Cabana G, Rasmussen JB (1996) Comparison of aquatic food chains using nitrogen isotopes. Proc Natl Acad Sci 93: 10844-10847

Calef GW, Grice GD (1966) Relationship between the blue green alga Trichodesmium thiebautii and the copepod Macrosetella gracilis in the plankton off north-eastern South America. Ecology 47:855-856

Capone DG, Zehr JP, Paerl HW, Bergman B, Carpenter EJ (1997) Trichodesmium, a globally significant marine cyanobacterium. Science 276:1221-1230

Carpenter EJ, Harvey RH, Fry B, Capone DG (1997) Biogeochemical tracers of the marine cyanobacterium Trichodesmium. Deep-Sea Res 44:27-38

Carpenter EJ, Montoya JP, Burns J, Mulholland MR, Subramaniam A, Capone DG (1999) Extensive bloom of a $\mathrm{N}_{2}$ fixing diatom/cyanobacterial association in the tropical Atlantic Ocean. Mar Ecol Prog Ser 185:273-283

Carpenter EJ, Subramaniam A, Capone DG (2003) Biomass and primary productivity of the cyanobacterium Trichodesmium spp. in the tropical N Atlantic. Deep-Sea Res Part I 52:1021-1041

Cox PA, Banack SA, Murch SJ, Rasmussen U and 6 others (2005) Diverse taxa of cyanobacteria produce $\beta$-N-methylamino-L-alanine, a neurotoxic amino acid. Proc Natl Acad Sci 102:5074-5078

DeNirot MJ, Epstein S (1981) Influence of diet on the distribution of nitrogen isotopes in animals. Geochim Cosmochim Acta 45:341-351

Hawser SP, Carpenter EJ, Capone DG (1991) A neurotoxic factor associated with the bloom-forming cyanobacterium Trichodesmium. Toxicon 29:277-278

Hawser SP, O'Neil JM, Roman MR, Codd MR (1992) Toxicity of blooms of the cyanobacterium Trichodesmium to zooplankton. J Appl Phycol 4:79-86

Huys R, Böttger-Schnack R (1994) Taxonomy, biology and phylogeny of Miracidae (Copepoda: Harpacticoida). Sarsia 79:207-283

Hwang J, Turner J (1995) Behaviour of cyclopoid, harpacticoid and calanoid copepods from coastal waters of Taiwan. PSZN I: Mar Ecol 16:207-216

Editorial responsibility: Howard Browman (Associate Editorin-Chief), Storebø, Norway
Jennings S, Warr KJ (2003) Environmental correlates of largescale spatial variation in the $\delta^{15} \mathrm{~N}$ of marine animals. Mar Biol 142:1131-1140

Krishnaswamy S (1949) Development of a harpacticoid copepod, Macrosetella gracilis (Dana). J Madras Univ 26: $256-271$

Lajtha K, Michener RM (1994) Stable isotopes in ecology and environmental science. Blackwell Scientific Publications, Oxford

Letelier RM, Karl DM (1996) Role of Trichodesmium spp. in the productivity of the subtropical North Pacific. Mar Ecol Prog Ser 133:263-273

Michener RM, Schell DM (1994) Stable isotope ratios as tracers in marine aquatic foodwebs. In: Lajtha K, Michener RM (eds) Stable isotopes in ecology and environmental science. Blackwell Scientific Publications, Oxford, p 138-157

Minagawa M, Wada E (1986) Nitrogen isotope ratios of red tide organisms in the East China Sea: a characterization of biological nitrogen fixation. Mar Chem 19:245-259

Montoya JJ, Carpenter EJ, Capone DJ (2002) Nitrogen fixation and nitrogen isotope abundances in zooplankton of the oligotrophic North Atlantic. Limnol Oceanogr 47:1617-1628

Ohtsuka S, Kubo N, Okada M, Gushima K (1993) Attachment and feeding of pelagic copepods on larvacean houses. J Oceanogr 49:115-120

O'Neil JM (1998) The colonial cyanobacterium Trichodesmium as a physical and nutritional substrate for the harpacticoid copepod Macrosetella gracilis. J Plankton Res 20:43-59

O'Neil JM (1999) Grazer interactions with nitrogen-fixing marine cyanobacteria: adaptation for N-acquisition? Bull Inst Oceanogr Monaco Spec Issue 19:293-317

O'Neil JM, Roman MR (1994) Ingestion of the cyanobacterium Trichodesmium spp. by pelagic copepods Macrosetella, Miracia and Oculosetella. Hydrobiologia 292/293: 235-240

O'Neil JM, Metzeler P, Gilbert PM (1996) Ingestion of ${ }^{15} \mathrm{~N}_{2}$ labelled Trichodesmium, and ammonium regeneration by the pelagic harpacticoid copepod Macrosetella gracilis. Mar Biol 125:89-96

Peterson BJ, Fry B (1987) Stable isotopes in ecosystem studies. Annu Rev Ecol Syst 18:293-320

Post AF, Dedej Z, Gottlieb R, Li H and 5 others (2002) Spatial and temporal distribution of Trichodesmium spp. in the stratified Gulf of Aqaba, Red Sea. Mar Ecol Prog Ser 239: 241-250

Roman MR (1978) Ingestion of the blue-green alga Trichodesmium by the harpacticoid copepod, Macrosetella gracilis. Limnol Oceanogr 23:1245-1247

Sheridan CC, Steinberg DK, Kling GW (2002) The microbial and metazoan community associated with colonies of Trichodesmium spp.: a quantitative survey. J Plankton Res 24:913-922

Sokal RR, Rohlf FJ (1995) Biometry. Freeman \& Co, New York

Steinberg DK (1994) Midwater zooplankton communities on pelagic detritus (giant larvacean houses) in Monterey Bay California. Limnol Oceanogr 39:1606-1620

Tokioka T, Bieri R (1966) Juveniles of Macrosetella gracilis (Dana) from clumps of Trichodesmium in the vicinity of Seto. Publ Seto Mar Biol Lab 14:177-184

Wada E, Hattori A (1991) Nitrogen in the sea: forms, abundances and rate processes. CRC Press, Boca Raton

Submitted: May 5, 2006; Accepted: August 10, 2006

Proofs received from author(s): February 22, 2007 